\title{
Impacts of anthropogenic and natural sources on free tropospheric ozone over the Middle East
}

\author{
Zhe Jiang $^{1, \text { a }}$, Kazuyuki Miyazaki ${ }^{2}$, John R. Worden ${ }^{1}$, Jane J. Liu ${ }^{3,4}$, Dylan B. A. Jones ${ }^{5}$, and Daven K. Henze \\ ${ }^{1}$ Jet Propulsion Laboratory, California Institute of Technology, Pasadena, CA, USA \\ ${ }^{2}$ Japan Agency for Marine-Earth Science and Technology, Yokohama, Japan \\ ${ }^{3}$ Department of Geography and Planning, University of Toronto, Toronto, ON, Canada \\ ${ }^{4}$ School of Atmospheric Sciences, Nanjing University, Nanjing, China \\ ${ }^{5}$ Department of Physics, University of Toronto, Toronto, ON, Canada \\ ${ }^{6}$ Department of Mechanical Engineering, University of Colorado, Boulder, CO, USA \\ anow at: National Center for Atmospheric Research, Boulder, CO, USA
}

Correspondence to: Zhe Jiang (zhejiang@ucar.edu)

Received: 13 October 2015 - Published in Atmos. Chem. Phys. Discuss.: 16 December 2015

Revised: 4 May 2016 - Accepted: 18 May 2016 - Published: 27 May 2016

\begin{abstract}
Significant progress has been made in identifying the influence of different processes and emissions on the summertime enhancements of free tropospheric ozone $\left(\mathrm{O}_{3}\right)$ at northern midlatitude regions. However, the exact contribution of regional emissions, chemical and transport processes to these summertime enhancements is still not well quantified. Here we focus on quantifying the influence of regional emissions on the summertime $\mathrm{O}_{3}$ enhancements over the Middle East, using updated reactive nitrogen $\left(\mathrm{NO}_{x}\right)$ emissions. We then use the adjoint of the GEOS-Chem model with these updated $\mathrm{NO}_{x}$ emissions to show that the global total contribution of lightning $\mathrm{NO}_{x}$ on middle free tropospheric $\mathrm{O}_{3}$ over the Middle East is about 2 times larger than that from global anthropogenic sources. The summertime middle free tropospheric $\mathrm{O}_{3}$ enhancement is primarily due to Asian $\mathrm{NO}_{x}$ emissions, with approximately equivalent contributions from Asian anthropogenic activities and lightning. In the Middle Eastern lower free troposphere, lightning $\mathrm{NO}_{x}$ from Europe and North America and anthropogenic $\mathrm{NO}_{x}$ from Middle Eastern local emissions are the primary sources of $\mathrm{O}_{3}$. This work highlights the critical role of lightning $\mathrm{NO}_{x}$ on northern midlatitude free tropospheric $\mathrm{O}_{3}$ and the important effect of the Asian summer monsoon on the export of Asian pollutants.
\end{abstract}

\section{Introduction}

$\mathrm{O}_{3}$ is produced in the troposphere when volatile organic compounds (VOC) and carbon monoxide $(\mathrm{CO})$ are photochemically oxidized in the presence of $\mathrm{NO}_{x}$. Tropospheric $\mathrm{O}_{3}$ is an important pollutant and greenhouse gas. It also plays a critical role in determining the oxidizing capacity of the troposphere. The $\mathrm{O}_{3}$ distribution in the troposphere is strongly influenced by dynamical processes, as well as by the regional chemical sources and sinks of $\mathrm{O}_{3}$. Previous studies (e.g., Park et al., 2007; Worden et al., 2009; Vogel et al., 2014) have demonstrated that rapid convective transport associated with the Asian monsoon anticyclone can result in significant enhancement of $\mathrm{O}_{3}$ abundance over Asia, northern Africa and Europe. The stratosphere-troposphere exchange of $\mathrm{O}_{3}$ also has important effects on the distribution of tropospheric $\mathrm{O}_{3}$ (e.g., Barth et al., 2012; Neu et al., 2014).

Tropospheric $\mathrm{O}_{3}$ peaks in the summer in broad regions of the Northern Hemispheric middle latitudes (Zanis et al., 2007; Cristofanelli et al., 2014). Recent studies (e.g., Liu et al., 2009; Worden et al., 2009; Zanis et al., 2014) showed that the summertime maximum in free tropospheric $\mathrm{O}_{3}$ over the Middle East as observed by the Tropospheric Emission Spectrometer (TES) was consistent with the model predictions of Li et al. (2001). Liu et al. (2009) indicated that the enhancement of free tropospheric $\mathrm{O}_{3}$ over the Middle East is mainly due to the influence of the Arabian anticyclone in the middle troposphere, which traps $\mathrm{O}_{3}$ that is produced locally as 
well as $\mathrm{O}_{3}$ and its precursors that are transported from rest of Asia. Recent studies (Ricaud et al., 2014; Vogel et al., 2014) demonstrated that the Asian monsoon anticyclone provides an effective pathway to redistribute Asian pollutants globally. An improved understanding about the mechanism of the summertime enhancement of free tropospheric $\mathrm{O}_{3}$ over the Middle East is thus important as it will provide critical information about the sources and variation of tropospheric $\mathrm{O}_{3}$ in the Northern Hemisphere.

In this study, we assess the influence of anthropogenic and natural sources of $\mathrm{O}_{3}$ precursors on free tropospheric $\mathrm{O}_{3}$ enhancement over the Middle East. During the past decade there have been several studies using data assimilation and inverse modeling approaches to better quantify the emission estimates of $\mathrm{O}_{3}$ precursors (e.g., Fu et al., 2007; Lamsal et al., 2011; Miyazaki et al., 2012; Jiang et al., 2015a). In order to better represent the emission change in the past decade in our analysis, we adopted the most recent updated $\mathrm{NO}_{x}$ emission estimates from the assimilation study of Miyazaki et al. (2015) for the period of 2005-2012, which employed remote-sensing measurements from OMI (Ozone Monitoring Instrument), MLS (Microwave Limb Sounder), TES and MOPITT (Measurement of Pollution In The Troposphere). Miyazaki et al. (2015) obtained significant bias reductions for $\mathrm{O}_{3}$ and nitrogen dioxide $\left(\mathrm{NO}_{2}\right)$, relative to satellite and ozonesonde measurements. Use of their updated $\mathrm{NO}_{x}$ emission estimates is, therefore, expected to provide a better simulation of tropospheric $\mathrm{O}_{3}$ than the Global Emissions Inventory Activity (GEIA) (Benkovitz et al., 1996) used by Liu et al. (2009). In their analysis, Liu et al. (2009) used the tagging capability of the GEOS-Chem model to quantify the regional influence on the Middle East $\mathrm{O}_{3}$ maximum, based on the linearized $\mathrm{O}_{3}$ production and loss rate. However, that approach cannot track $\mathrm{O}_{3}$ sources back to emissions of $\mathrm{O}_{3}$ precursors and only provides a coarse aggregation of the regional contributions. Here, following Jiang et al. (2015b), we use the adjoint of the GEOS-Chem model to carry out a more detailed sensitivity analysis, which will allow us to better distinguish the contributions of different regions and emission categories to free tropospheric $\mathrm{O}_{3}$ over the Middle East.

\section{GEOS-Chem model with updated surface $\mathrm{NO}_{x}$ emissions}

The GEOS-Chem CTM (http://www.geos-chem.org) is driven by assimilated meteorological data from the NASA Goddard Earth Observing System (GEOS-5) at the Global Modeling and Assimilation Office. We used version v34 of the GEOS-Chem adjoint model, which is based on v802-01 of GEOS-Chem with relevant updates through v901-01. The standard GEOS-Chem chemical mechanism includes 43 tracers, which can simulate detailed tropospheric $\mathrm{O}_{3}-\mathrm{NO}_{x}$-hydrocarbon chemistry, including the radiative and heterogeneous effects of aerosols. The global anthropogenic emission inventory is EDGAR 3.2 FT2000 (Olivier and Berdowski, 2001), updated by the following regional emission inventories: the INTEX-B Asia emissions inventory for 2006 (Zhang et al., 2009); the cooperative program for monitoring and evaluation of the long-range transmission of air pollutants, the European Monitoring and Evaluation Programme (EMEP) inventory for Europe in 2000 (Vestreng and Klein, 2002); the US Environmental Protection Agency National Emission Inventory (NEI) for 2005 in North America; the Criteria Air Contaminants (CAC) inventory for Canada; and the Big Bend Regional Aerosol and Visibility Observational (BRAVO) Study Emissions Inventory for Mexico (Kuhns et al., 2003). Biomass burning emissions are from the interannual GFED3 inventory (van der Werf et al., 2010). The soil $\mathrm{NO}_{x}$ emission scheme is based on Yienger and Levy (1995) and Wang et al. (1998), as a function of vegetation type, temperature, precipitation history and fertilizer usage. The emissions of biogenic volatile organic compounds (VOCs) are from MEGAN 2.0 (Millet et al., 2008).

We adopted the updated surface $\mathrm{NO}_{x}$ emission estimates from Miyazaki et al. (2015) for the period 2005-2012. Using the combined assimilation of remote-sensing measurements from OMI $\mathrm{NO}_{2}$, MLS and TES $\mathrm{O}_{3}$, and MOPITT CO, Miyazaki et al. (2015) constrained $\mathrm{NO}_{x}$ emissions as well as lightning $\mathrm{NO}_{x}$ sources and the chemical concentration of various species in the troposphere with the CHASER model (Sudo and Akimoto, 2007). The analysis was conducted with a local ensemble transform Kalman filter (LETKF) method, with 30 ensembles and a $450 \mathrm{~km}$ horizontal localization scale for surface $\mathrm{NO}_{x}$ emissions. A major advantage of the multispecies data assimilation used in Miyazaki et al. (2015) is that observations of one species (for example, $\mathrm{O}_{3}$ ) can provide additional constraints on other species (for example, $\mathrm{NO}_{x}$ ) through the improvement in atmospheric fields and emission fluxes influencing the $\mathrm{NO}_{x}$ chemistry. In 2005, the assimilation resulted in a $25 \%$ increase in $\mathrm{NO}_{x}$ emissions for Asia, relative to the GEOS-Chem a priori emissions. The adjustments for $\mathrm{NO}_{x}$ emissions from Europe and North America were much smaller. The inversion result was evaluated with independent data from satellite, aircraft, ozonesonde and surface in situ measurements, which demonstrated large bias reductions after assimilation. For free tropospheric $\mathrm{O}_{3}$, the mean model bias relative to ozonesonde measurements was reduced from -2.3 to $0.4 \mathrm{ppb}$ in the tropics and -1.4 to $0.9 \mathrm{ppb}$ in the Northern Hemisphere after assimilation, in which the surface $\mathrm{NO}_{x}$ emission optimization played a crucial role in reducing the model bias in the lower and middle troposphere (Miyazaki et al., 2015). It should be noted that we did not use the updated lightning $\mathrm{NO}_{x}$ emissions in this work, because of the larger uncertainties for those emission estimates (e.g., spurious variations were introduced because of the lack of constraints from the TES measurements after 2010). Because of the limitation of short horizontal localization length (with the cut-off radius of $1643 \mathrm{~km}$ ) and the short data assimilation window (i.e., $2 \mathrm{~h}$ ), the influence of long- 


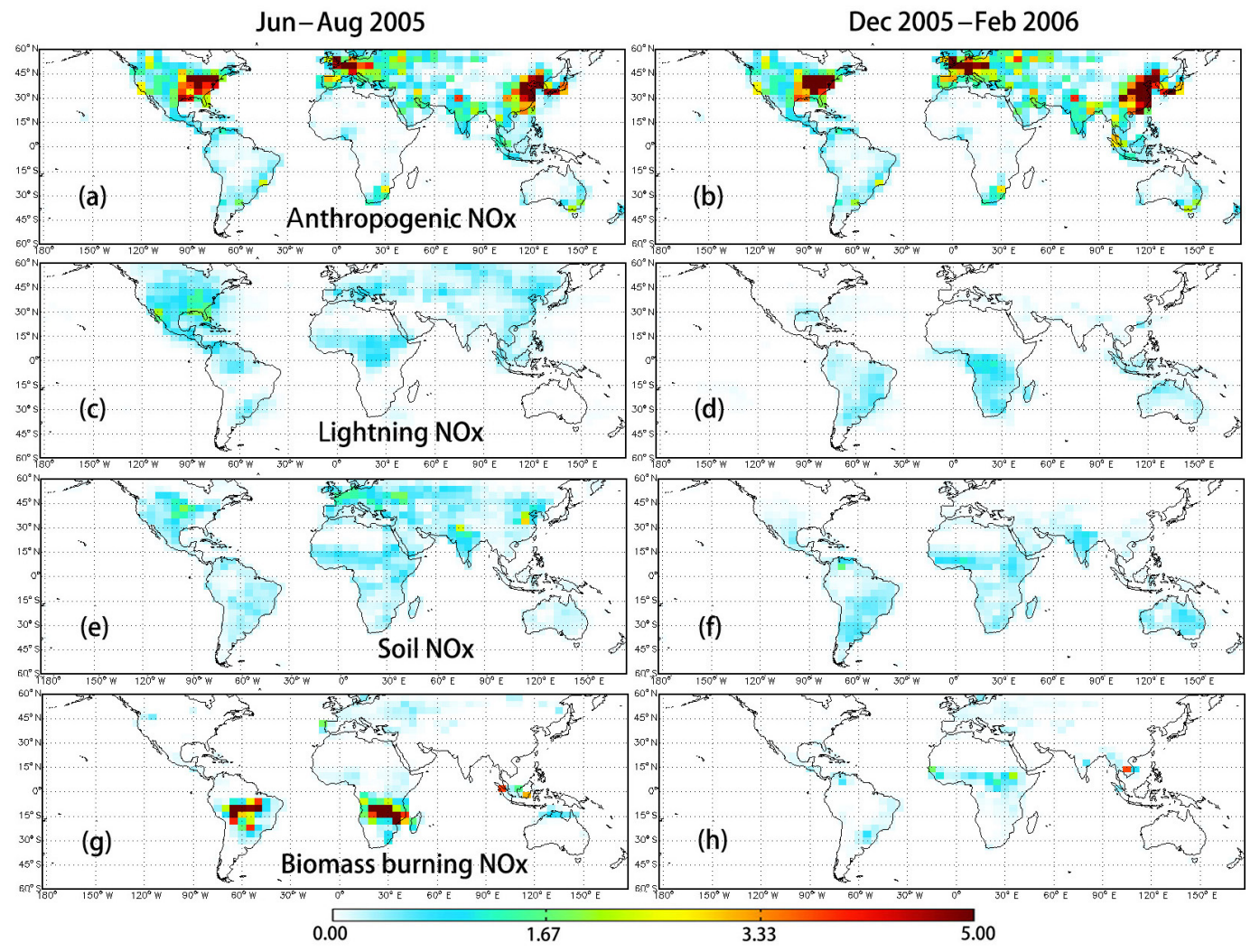

Figure 1. Seasonal mean $\mathrm{NO}_{x}$ emission from anthropogenic, lightning, soil and biomass burning. The unit is $10^{10} \mathrm{molec}^{-2} \mathrm{~s}^{-1}$.

range transport processes cannot be sufficiently considered in the data assimilation framework of Miyazaki et al. (2015), and thus, the estimated $\mathrm{CO}$ emissions may have large uncertainty. Therefore, we did not use the optimized $\mathrm{CO}$ emissions in this work. In 2005, the global total lightning $\mathrm{NO}_{x}$ source in the GEOS-Chem simulation is $6.0 \mathrm{Tg} \mathrm{N}$; the value is within the range of recent best estimates (e.g., $5 \pm 3 \mathrm{Tg} \mathrm{Nyr}^{-1}$ in Schumann and Huntrieser, 2007, and 6.3 $\pm 1.4 \mathrm{Tg} \mathrm{N} \mathrm{yr}^{-1}$ in Miyazaki et al., 2014).

Figure 1 shows $\mathrm{NO}_{x}$ emissions from anthropogenic activities, lightning, soil and biomass burning emissions in the model. There are strong anthropogenic emissions from eastern Asia, eastern North America and Europe, and the emission strengths are nearly constant between summer and winter. The seasonality of lightning and soil $\mathrm{NO}_{x}$ are similar: more $\mathrm{NO}_{x}$ emissions in the summer hemisphere, but the emission strength is lower than that for the anthropogenic sources. The emissions from biomass burning have strong seasonality, generally peaking in the biomass burning seasons.

\section{Summertime enhancement of free tropospheric ozone over the Middle East}

The TES instrument was launched on NASA's Aura spacecraft on 15 July 2004. The satellite is in a sun-synchronous polar orbit of $705 \mathrm{~km}$ and crosses the equator at 01:45 and 13:45 LT. With a footprint of $8 \mathrm{~km} \times 5 \mathrm{~km}$, TES measures radiances between 3.3 and $15.4 \mu \mathrm{m}$ with global coverage of 16 days (Beer et al., 2001) of observations. In the troposphere, TES $\mathrm{O}_{3}$ profile retrievals have 1-2 degrees of freedom for signal (DOFS). We use data from the "lite" product (http://tes.jpl.nasa.gov/data/), which reports volume mixing ratios (VMR) on 26 pressure levels for $\mathrm{O}_{3}$. The TES retrievals use a monthly mean profile of the trace gas from the MOZART-4 CTM (chemical transport model), averaged over $10^{\circ}$ latitude $\times 60^{\circ}$ longitude, as the a priori information. We refer the reader to Jiang et al. (2015b) for more details about the application and evaluation of TES $\mathrm{O}_{3}$ data.

Figure $2 \mathrm{a}-\mathrm{d}$ present the modeled middle free tropospheric (464 hPa) $\mathrm{O}_{3}$ distribution for March 2005-February 2006. An obvious feature is the low $\mathrm{O}_{3}$ concentrations over the maritime continent and the Amazon, which is consistent with previous studies using measurements from satellite, ozonesonde and aircraft (Rex et al., 2014; Bela et al., 2015). Over the northern middle latitudes, $\mathrm{O}_{3}$ concentrations are highest in summer. The tropospheric $\mathrm{O}_{3}$ concentrations in 


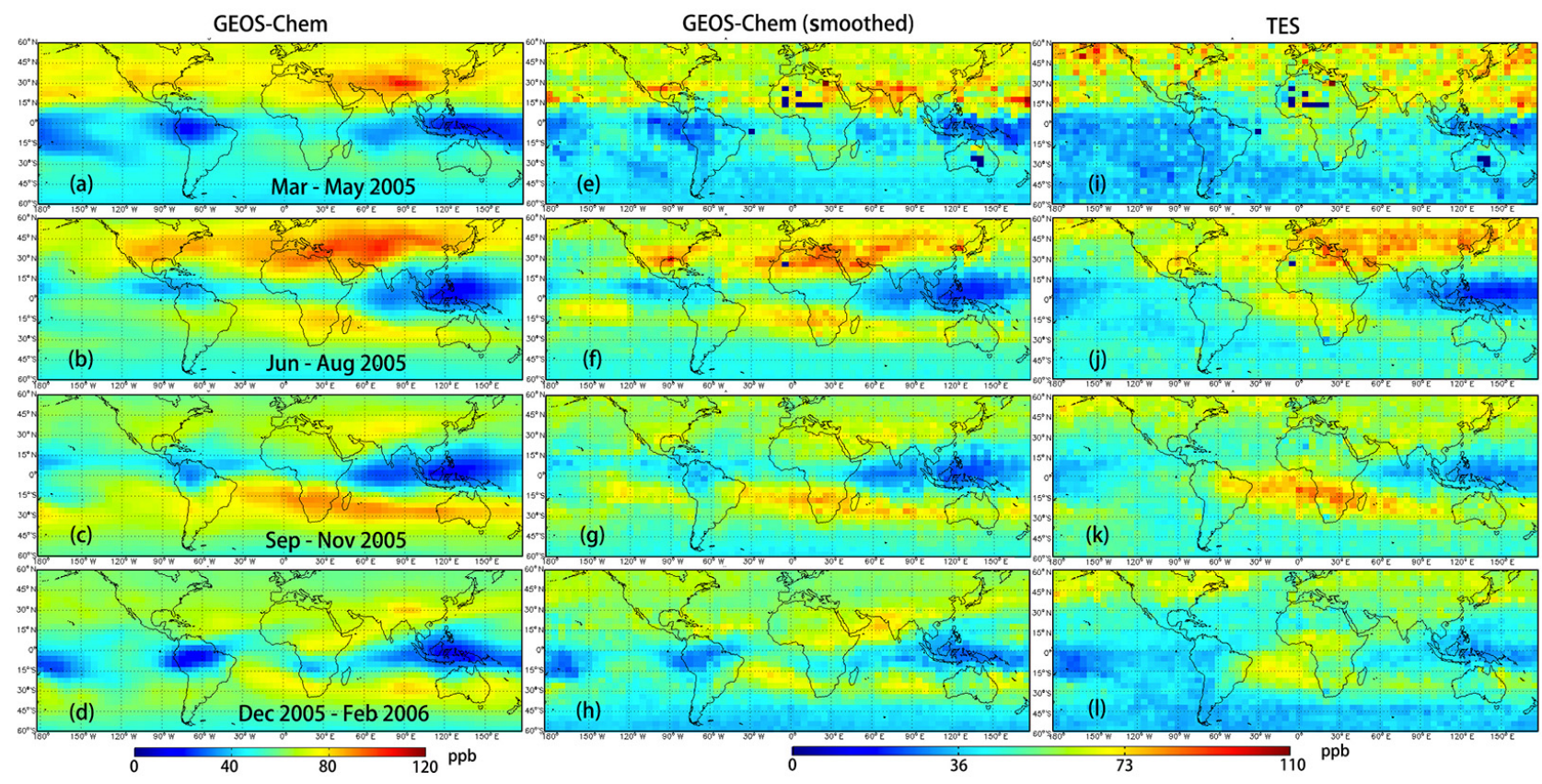

Figure 2. Seasonal mean middle free tropospheric $\mathrm{O}_{3}(464 \mathrm{hPa})$ in the period of March 2005-February 2006. (a-d) GEOS-Chem simulation. (e-h) GEOS-Chem simulation smoothed with TES averaging kernel and a priori. (i-l) $\mathrm{TES} \mathrm{O}_{3}$ retrievals.

the middle troposphere start to increase in spring and then decrease dramatically in fall, which is consistent with seasonal cycle observed at European mountain sites (Zanis et al., 2007; Cristofanelli et al., 2014). Figure 2e-h show the modeled middle tropospheric $(464 \mathrm{hPa}) \mathrm{O}_{3}$ smoothed with the TES averaging kernels and a priori. The unsmoothed (Fig. 2a-d) and smoothed (Fig. 2e-h) $\mathrm{O}_{3}$ distributions are highly consistent, although there is a small difference in the magnitude. Figure $2 \mathrm{i}-1$ present the TES $\mathrm{O}_{3}$ retrievals at $464 \mathrm{hPa}$, which demonstrates good agreement globally with respect to the model.

Figure 3 shows the monthly variation of mean $\mathrm{O}_{3}$ over the Middle East at different levels. In the lower and middle troposphere, the relative difference between the model and data is generally less than $10 \%$, whereas the bias is a little larger in the upper troposphere. Figure 3 shows significant and moderate $\mathrm{O}_{3}$ enhancement during the summer in the middle and lower troposphere, respectively, over the Middle East. In contrast, $\mathrm{O}_{3}$ concentrations in the upper troposphere are at a minimum in summer, implying altitude-dependent mechanisms for the $\mathrm{O}_{3}$ variations. Obtaining a better understanding of these mechanisms is important because it provides critical insights about the sources and variations of tropospheric $\mathrm{O}_{3}$ in the Northern Hemisphere.

\section{Impact of anthropogenic and natural sources on the Middle East ozone}

Liu et al. (2009) indicated that $\mathrm{O}_{3}$ production over the Middle East and rest of Asia both contribute about $30 \%$ of free tropospheric $\mathrm{O}_{3}$ over the Middle East in July 2005. However, due to the limitation of the tagging approach that they employed, they were not able to obtain a detailed description of the sensitivity of Middle East $\mathrm{O}_{3}$ to the precursor emissions. In this section, we will use the adjoint of the full-chemistry GEOS-Chem model (Henze et al., 2007) to quantify $\mathrm{O}_{3}$ source contributions, similar to previous studies (Lapina et al., 2014; Jiang et al., 2015b). The adjoint model, which includes both chemistry and transport, is run backwards to computationally efficiently provide sensitivities with respect to each of the model's emissions from each species, sector and grid cell.

Figure 4 shows the response of $\mathrm{O}_{3}$ in the lower free troposphere (700-600 hPa) and middle troposphere (450-350 hPa) over the Middle East $\left(30-60^{\circ} \mathrm{E}, 20-40^{\circ} \mathrm{N}\right)$ to $\mathrm{O}_{3}$ precursor emission perturbation for June-August 2005. The response can be explained as the mean change (unit of ppbv) of regional mean $\mathrm{O}_{3}$ due to $10 \%$ increase of $\mathrm{O}_{3}$ precursor emissions in a particular grid assuming unchanged chemical environment. For example, one particular grid with response $0.02 \mathrm{ppb}$ implies mean free tropospheric $\mathrm{O}_{3}$ over the Middle East will be increased by $0.02 \mathrm{ppb}$, if the $\mathrm{O}_{3}$ precursor emission in this grid is increased by $10 \%$ under current chemical regime. 


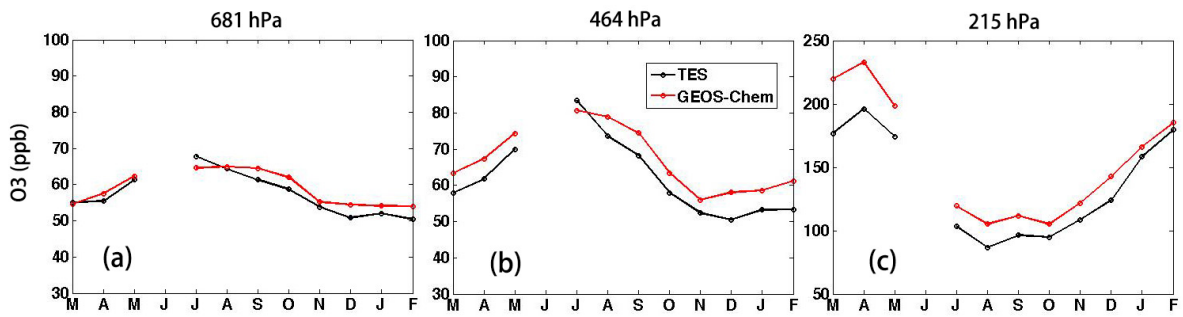

Figure 3. Monthly mean $\mathrm{O}_{3}$ concentration for lower free troposphere $(681 \mathrm{hPa})$, middle free troposphere $(464 \mathrm{hPa})$ and upper free troposphere $(215 \mathrm{hPa})$ in the period of March 2005-February 2006 over Middle Eastern Asia (blue box in Fig. 4) for TES O 3 retrievals and GEOS-Chem simulation (smoothed with TES averaging kernel and a priori). There is no TES data available in June 2005.

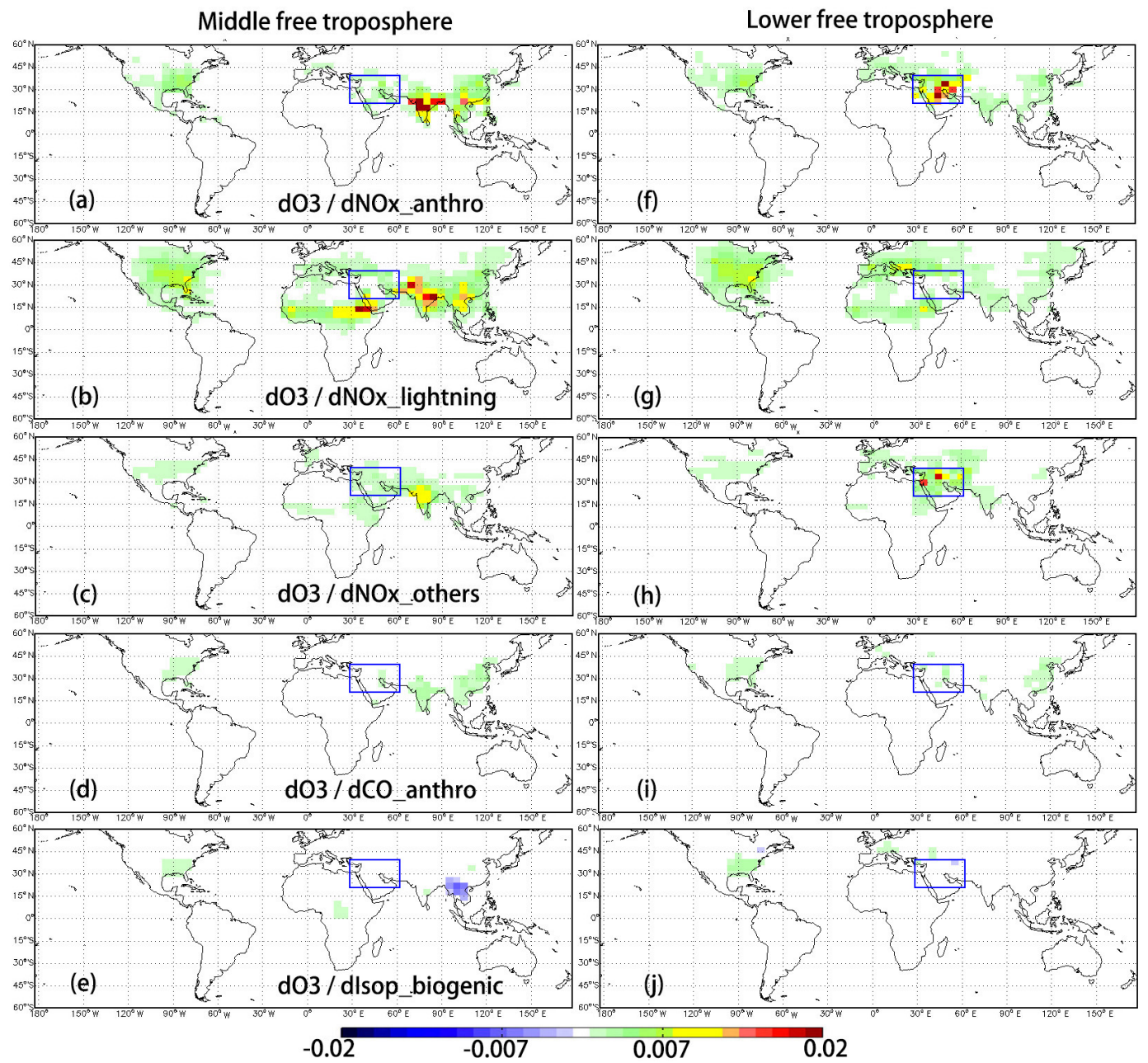

Figure 4. Response of middle free tropospheric $(450-350 \mathrm{hPa})$ and lower free tropospheric (700-600 hPa) $\mathrm{O}_{3}$ over Middle Eastern Asia (blue box) to precursor emission perturbation from anthropogenic $\mathrm{NO}_{x}$, lightning $\mathrm{NO}_{x}$, other $\mathrm{NO}_{x}$ sources (biomass burning, biofuel and soil $\mathrm{NO}_{x}$ ), anthropogenic $\mathrm{CO}$ and biogenic isoprene, for June-August 2005. The response can be explained as the mean change (unit of ppbv) of regional mean $\mathrm{O}_{3}$ due to $10 \%$ increase of precursor emissions in a particular grid assuming unchanged chemical environment.

In the middle troposphere, anthropogenic and natural $\mathrm{NO}_{x}$ emissions from Asia, particularly from India, are the primary sources of $\mathrm{O}_{3}$ precursors and subsequent $\mathrm{O}_{3}$ production (Fig. 4a). In contrast, $\mathrm{O}_{3}$ and $\mathrm{O}_{3}$ production in the lower free troposphere depends primarily on $\mathrm{NO}_{x}$ emissions in the
Middle East, but with significant contributions from natural and anthropogenic sources elsewhere in the Northern Hemisphere. This distinct difference in source regions for $\mathrm{O}_{3}$, between the middle and lower free troposphere, highlights the complex transport pathways that bring air from other parts 
Table 1. Response of middle free tropospheric $(450-350 \mathrm{hPa}) \mathrm{O}_{3}$ over Middle Eastern Asia $\left(30-60^{\circ} \mathrm{E}, 20-40^{\circ} \mathrm{N}\right)$ to $\mathrm{NO} x$ emission perturbation in the period of March 2005-February 2006. The value can be explained as the mean change (unit of ppbv) of regional mean $\mathrm{O}_{3}$ due to $10 \%$ increase of $\mathrm{NO}_{x}$ emission in a particular region (Asia, North America (NA) and Europe (EU), Middle Eastern Asia, and the rest of the world) assuming unchanged chemical environment. The last column shows the multiyear mean value for June-August 2005-2012.

\begin{tabular}{llllllr}
\hline \multirow{2}{*}{ Middle free troposphere } & Jun-Aug & Sep-Nov & Dec-Feb & Mar-May & $\begin{array}{r}\text { Jun-Aug } \\
\text { 2005-2012 }\end{array}$ \\
\hline \multirow{3}{*}{ Asia } & Anthro & 0.40 & 0.17 & 0.09 & 0.13 & 0.38 \\
& Lightning & 0.53 & 0.21 & 0.08 & 0.22 & 0.47 \\
\cline { 2 - 7 } & Total & 0.93 & 0.37 & 0.17 & 0.35 & 0.85 \\
\hline \multirow{3}{*}{ NA and EU } & Anthro & 0.11 & 0.13 & 0.06 & 0.14 & 0.11 \\
& Lightning & 0.34 & 0.28 & 0.10 & 0.31 & 0.35 \\
\cline { 2 - 7 } Middle East & Total & 0.45 & 0.41 & 0.16 & 0.45 & 0.46 \\
\cline { 2 - 7 } & Anthro & 0.04 & 0.03 & 0.01 & 0.03 & 0.07 \\
\cline { 2 - 7 } Rest of world & Total & 0.12 & 0.05 & 0.02 & 0.08 & 0.15 \\
\cline { 2 - 7 } & Anthro & 0.01 & 0.04 & 0.04 & 0.03 & 0.02 \\
\cline { 2 - 7 } & Lightning & 0.33 & 0.55 & 0.46 & 0.40 & 0.33 \\
\hline \multirow{3}{*}{ Global } & Total & 0.34 & 0.58 & 0.51 & 0.43 & 0.35 \\
\hline \multirow{3}{*}{ Others } & Anthro & 0.57 & 0.36 & 0.20 & 0.34 & 0.58 \\
\cline { 2 - 7 } & Total & 1.85 & 1.42 & 0.85 & 1.32 & 1.81 \\
\hline \multirow{3}{*}{ Lightning } & 1.28 & 1.06 & 0.65 & 0.98 & 0.38 \\
\hline
\end{tabular}

of the world to this region (e.g., Liu et al., 2011; Safieddine et al., 2014). For both the lower and middle free troposphere, the contributions from other source types, primarily $\mathrm{NO}_{x}$ from biofuel and soil emissions, or biomass burning, are less significant in this season. The contributions from anthropogenic $\mathrm{CO}$ and biogenic isoprene are small in this season, indicating that $\mathrm{O}_{3}$ production is primarily $\mathrm{NO}_{x}$ limited, and thus, we will focus on the contributions of $\mathrm{NO}_{x}$ to $\mathrm{O}_{3}$ in the following discussions.

Table 1 provides the seasonal mean value of the response of Middle Eastern $\mathrm{O}_{3}$ in the middle troposphere (450$350 \mathrm{hPa}$ ) to $\mathrm{NO}_{x}$ perturbations between March 2005 and February 2006. The analysis shows a maximum total global response $(1.85 \mathrm{ppb})$ in summer, corresponding to the summertime $\mathrm{O}_{3}$ maximum. The total global contribution from lightning $\mathrm{NO}_{x}$ is about 2 times larger than that from anthropogenic emissions in all seasons, implying that lightning $\mathrm{NO}_{x}$ is the dominant source for middle free tropospheric $\mathrm{O}_{3}$ over the Middle East, which is consistent with Liu et al. (2009), who indicated that most free tropospheric $\mathrm{O}_{3}$ (about $75 \%$ ) over the Middle East is produced in the free troposphere ( $700 \mathrm{hPa}$ - tropopause).

During June-August 2005, the region that makes the largest contributions to $\mathrm{O}_{3}$ in the middle troposphere over the Middle East is Asia ( $0.93 \mathrm{ppb}$ ), followed by Europe and North America $(0.45 \mathrm{ppb})$. The contribution from Middle
Eastern local emissions is much smaller $(0.12 \mathrm{ppb})$, representing only $13 \%$ of Asian contributions. In contrast, Liu et al. (2009) found that $\mathrm{O}_{3}$ production (as opposed to emissions) over the Middle East and $\mathrm{O}_{3}$ production over Asia make contributions to free tropospheric $\mathrm{O}_{3}$ of similar magnitude, and the contribution from North America and Europe is negligible. The large discrepancy between these two studies implies that most $\mathrm{O}_{3}$ produced over the Middle East is due to imported $\mathrm{O}_{3}$ precursors from long-range transport, which would not be accounted for with the method employed by Liu et al. (2009), underscoring the significant role of long-range transport of $\mathrm{O}_{3}$ precursors on free tropospheric $\mathrm{O}_{3}$ production.

There are pronounced discrepancies between the seasonality of the regional contributions. For Asia, the total contribution to $\mathrm{O}_{3}$ in the Middle Eastern middle troposphere is $0.93 \mathrm{ppb}$ in summer, which is about 3 times larger than in spring $(0.35 \mathrm{ppb})$ and fall $(0.37 \mathrm{ppb})$. In contrast, the total contribution of Europe and North America is $0.45 \mathrm{ppb}$ in summer, similar as that in spring $(0.45 \mathrm{ppb})$ and fall $(0.41 \mathrm{ppb})$; the total contribution from the rest of the world is minimum in summer. The discrepancy in the seasonal variations suggests that Asian emissions are the main sources driving the summertime $\mathrm{O}_{3}$ maximum over the Middle East. Asian anthropogenic and lightning $\mathrm{NO}_{x}$ emissions have similar impacts, 0.40 and $0.53 \mathrm{ppb}$, respectively, on the Middle 

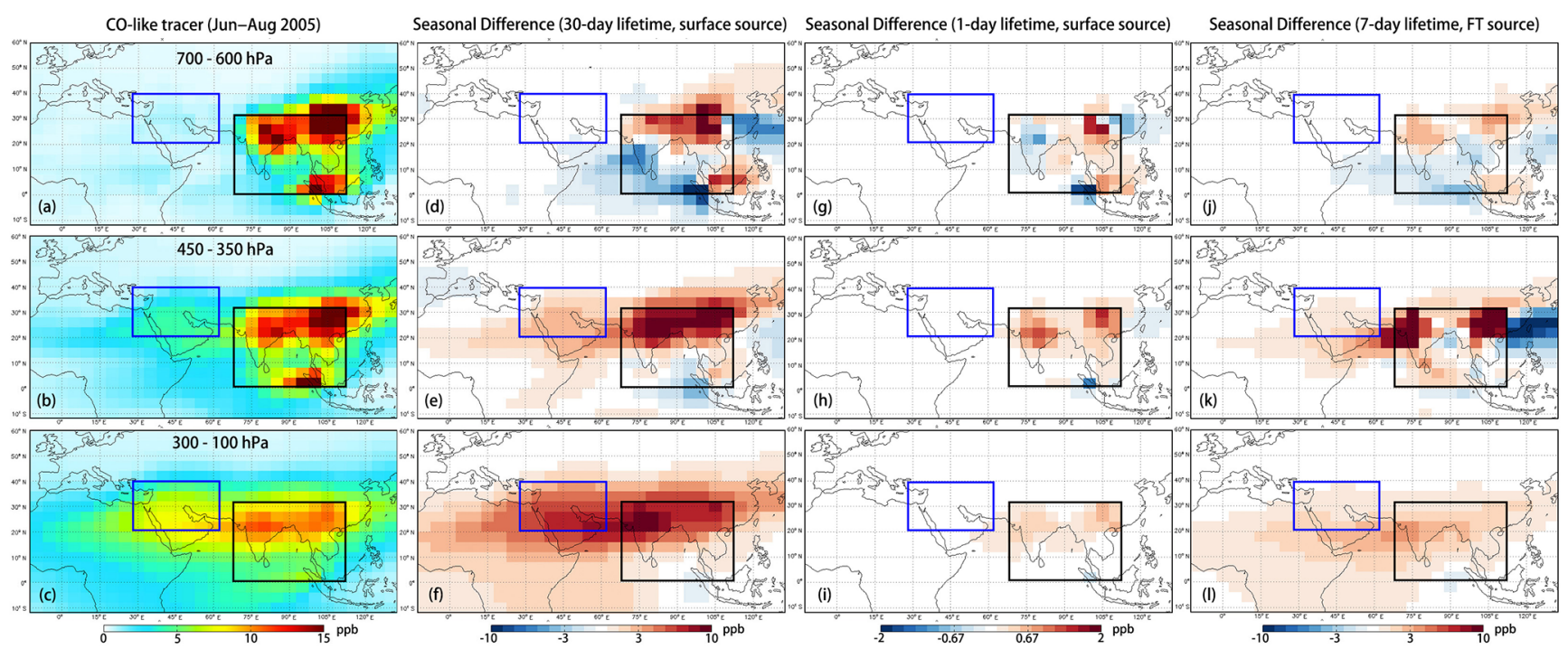

Figure 5. (a-c) Distribution of CO-like tracer (30-day lifetime) in June-August 2005 in lower free troposphere (700-600 hPa), middle free tropospheric $(450-350 \mathrm{hPa})$ and upper free tropospheric $(300-100 \mathrm{hPa})$. The blue box defines the Middle East domain. The black box defines the region where $\mathrm{CO}$ was released from combustion sources only (fossil fuel, biofuel and biomass burning); (d-f) difference of CO-like tracer (30-day lifetime) concentration between June-August and March-May 2005. The CO emission in March-May 2005 is set as the same as that in June-August 2005; (g-i) difference of CO-like tracer (1-day lifetime) concentration between June-August and March-May 2005; (j-l) difference of CO-like tracer (7-day lifetime) concentration between June-August and March-May 2005; the combustion sources are released in middle free troposphere.

Eastern summertime $\mathrm{O}_{3}$. It should be noted that the influence from stratosphere-troposphere exchange is not assessed in this work, as previous studies with GEOS-Chem model (Li et al., 2001; Liu et al., 2009) showed that the contribution from stratospheric $\mathrm{O}_{3}$ to the summertime $\mathrm{O}_{3}$ enhancement is small. More efforts are needed in the future to sufficiently evaluate the contribution of stratosphere-troposphere exchange, as suggested by some recent model studies (e.g., Lelieveld et al., 2009; Spohn and Rappenglück, 2014; Zanis et al., 2014).

To better understand the transport of Asian emissions to the Middle East, we conducted an analysis using an idealized CO-like tracer. We performed a tagged-CO simulation for the periods March-May and June-August 2005. Combustion $\mathrm{CO}$ emissions (fossil fuel, biofuel and biomass burning) are released over India and southeast Asia either from surface (Fig. 5a-i) or from middle free troposphere (Fig. 5j1). The CO emission in March-May 2005 is set as the same as that in June-August 2005. Following Jiang et al. (2015a), we assume a constant and uniform timescale for loss (lifetime). The simulations were initialized with a uniformly low abundance of $1 \mathrm{pptv}$ for the tracer.

With 30-day lifetime, our analysis shows significant influence from transport of Asian emissions to the upper free troposphere (Fig. 5c) in June-August 2005, associated with the Tibetan anticyclone. Figure $5 \mathrm{~d}-\mathrm{f}$ show the difference of COlike tracer concentrations between June-August and MarchMay 2005. Because the imposed emissions and sink for the tracer are constant, these differences are completely driven by seasonal variations in transport. Compared to spring, the transport of Asian emissions in summer has a moderate impact in the middle troposphere (Fig. 5e), but a significant influence in the upper troposphere (Fig. 5d). This shows the transport pathway during the Asian summer monsoon season is as follows: pollutants are lifted into upper troposphere through convection (e.g., Park et al., 2007; Worden et al., 2009) and trapped within the Tibetan anticyclone (e.g., Li et al., 2001). On the other hand, the enhancement of summertime $\mathrm{O}_{3}$ over the Middle East is at a maximum in the middle free troposphere (Fig. 3). This altitude discrepancy suggests the existence of other processes besides the Asian summer monsoon. As mentioned in the introduction, Liu et al. (2009) indicated that the Arabian anticyclone in the middle troposphere plays an important role in trapping the subsided $\mathrm{O}_{3}$ and its precursors in the Middle East, which is consistent with our results.

Over India and southeast Asia, the intensity of $\mathrm{NO}_{x}$ emissions from anthropogenic sources (Fig. 1a) is much larger than that from lightning (Fig. 1c), however, the contributions of anthropogenic and lightning emissions to middle free tropospheric $\mathrm{O}_{3}$ over the Middle East are similar (Fig. 4a, b). This discrepancy suggests that free tropospheric $\mathrm{NO}_{x}$ sources have larger impacts than surface sources on free tropospheric $\mathrm{O}_{3}$, associated with faster transport and longer lifetime in free troposphere. In order to evaluate the influence of source level, we conducted a model analysis by releasing 
Table 2. Response of lower free tropospheric (700-600 hPa) $\mathrm{O}_{3}$ over Middle Eastern Asia $\left(30-60^{\circ} \mathrm{E}, 20-40^{\circ} \mathrm{N}\right)$ to $\mathrm{NO}_{x}$ emission perturbation in the period of March 2005-February 2006. The last column shows the multiyear mean value for June-August $2005-2012$.

\begin{tabular}{|c|c|c|c|c|c|c|}
\hline \multicolumn{2}{|c|}{ Lower free troposphere } & \multirow{2}{*}{$\begin{array}{r}\text { Jun-Aug } \\
0.12\end{array}$} & \multirow{2}{*}{$\begin{array}{r}\text { Sep-Nov } \\
0.10\end{array}$} & \multirow{2}{*}{$\begin{array}{r}\text { Dec-Feb } \\
0.07\end{array}$} & \multirow{2}{*}{$\begin{array}{r}\text { Mar-May } \\
0.09\end{array}$} & \multirow{2}{*}{$\begin{array}{r}\text { Jun-Aug } \\
2005-2012 \\
0.11\end{array}$} \\
\hline \multirow{3}{*}{ Asia } & Anthro & & & & & \\
\hline & Lightning & 0.18 & 0.10 & 0.04 & 0.10 & 0.15 \\
\hline & Total & 0.29 & 0.20 & 0.11 & 0.20 & 0.26 \\
\hline \multirow{3}{*}{$\mathrm{NA}$ and $\mathrm{EU}$} & Anthro & 0.16 & 0.14 & 0.08 & 0.16 & 0.15 \\
\hline & Lightning & 0.47 & 0.28 & 0.09 & 0.23 & 0.46 \\
\hline & Total & 0.63 & 0.42 & 0.16 & 0.38 & 0.61 \\
\hline \multirow{3}{*}{ Middle East } & Anthro & 0.29 & 0.17 & 0.03 & 0.16 & 0.38 \\
\hline & Lightning & 0.07 & 0.04 & 0.02 & 0.06 & 0.07 \\
\hline & Total & 0.37 & 0.21 & 0.05 & 0.22 & 0.44 \\
\hline \multirow{3}{*}{ Rest of world } & Anthro & 0.03 & 0.03 & 0.04 & 0.04 & 0.03 \\
\hline & Lightning & 0.21 & 0.35 & 0.24 & 0.17 & 0.19 \\
\hline & Total & 0.23 & 0.38 & 0.27 & 0.21 & 0.22 \\
\hline \multirow{3}{*}{ Global } & Anthro & 0.59 & 0.44 & 0.21 & 0.45 & 0.67 \\
\hline & Lightning & 0.93 & 0.77 & 0.38 & 0.56 & 0.87 \\
\hline & Total & 1.52 & 1.22 & 0.60 & 1.00 & 1.54 \\
\hline Others & & 0.38 & 0.36 & 0.30 & 0.32 & 0.41 \\
\hline
\end{tabular}

(simulated) combustion $\mathrm{CO}$ emissions from the surface (1day lifetime, Fig. 5g-i) and middle free troposphere (7-day lifetime, Fig. 5j-1). The results confirmed the significant contribution from free tropospheric sources.

Table 2 provides the seasonal mean value of the $\mathrm{O}_{3}$ response in the Middle Eastern lower free troposphere $(700-600 \mathrm{hPa})$ to regional $\mathrm{NO}_{x}$ emissions. During JuneAugust 2005, the largest contribution $(0.63 \mathrm{ppb})$ to lower tropospheric $\mathrm{O}_{3}$ over the Middle East is from European and North American emissions, followed by Middle Eastern local emissions $(0.37 \mathrm{ppb})$. The large differences in regional contributions with altitude demonstrate the significant influence of dynamics on the distribution of free tropospheric $\mathrm{O}_{3}$. The global contribution from lightning $\mathrm{NO}_{x}$ is about 25$75 \%$ larger than that from anthropogenic emissions, implying lightning still plays an important role at these lower altitudes. Note that the lightning $\mathrm{NO}_{x}$ parameterization used in GEOS-Chem may have large uncertainties (e.g., Schumann and Huntrieser, 2007) and have influenced our estimates. For instance, the $\mathrm{C}$-shape assumption, with a first maximum in the upper troposphere and a second maximum in the boundary layer as proposed by Pickering et al. (1998), may place too much $\mathrm{NO}_{x}$ near the surface (Ott et al., 2010) and overestimate the peak source height over land and the tropical oceans (Miyazaki et al., 2014).

In order to isolate the potential influence of interannual variations in factors such as dynamics and biomass burn- ing, we conducted a sensitivity analysis for the period JuneAugust 2005-2012, using the updated surface $\mathrm{NO}_{x}$ emission estimates from Miyazaki et al. (2015). For the global total response in the middle free troposphere (Table 1), there is good consistency between the 2005 analysis (1.85 ppb) and 8-year mean value $(1.81 \mathrm{ppb})$. Small discrepancies are obtained for regional contributions; for example, the Asian contribution is $0.93 \mathrm{ppb}$ in 2005 , and $0.85 \mathrm{ppb}$ in the 8 -year mean value. Despite the small discrepancies, the consistency between the 2005 analysis and the 8-year mean values suggests that our conclusions based on the 2005 analysis provide a good representation for the free tropospheric $\mathrm{O}_{3}$ variation over the Middle East.

\section{Conclusions}

Remote sensing measurements from TES show a maximum in summertime free tropospheric $\mathrm{O}_{3}$ over the Middle East (Worden et al., 2009; Liu et al., 2009). Using updated $\mathrm{NO}_{x}$ emission estimates from Miyazaki et al. (2015), we conducted an adjoint sensitivity analysis to study the impact of anthropogenic and natural sources on free tropospheric $\mathrm{O}_{3}$ over the Middle East.

Our results reveal that the global total contribution of lightning $\mathrm{NO}_{x}$ on middle free tropospheric $\mathrm{O}_{3}$ over the Middle East is about 2 times larger than that from global anthropogenic sources. We find that emissions from Asia contribute 
the most to middle tropospheric $\mathrm{O}_{3}$ over the Middle East in summer, followed by European and North American emissions. The middle tropospheric $\mathrm{O}_{3}$ maximum in summer is driven by Asian emissions, with Asian anthropogenic and lightning $\mathrm{NO}_{x}$ emissions having similar contributions to the enhanced $\mathrm{O}_{3}$. Dynamics play a critical role on the buildup of middle free tropospheric $\mathrm{O}_{3}$ over the Middle East: $\mathrm{O}_{3}$ and its precursors are lifted into the upper troposphere through convection, trapped within the Tibetan anticyclone, and descend over the Middle East and are subsequently trapped within the Arabian anticyclone. In contrast, $\mathrm{O}_{3}$ in the lower free troposphere is influenced primarily by $\mathrm{O}_{3}$ precursor emissions in the Middle East, with significant contributions from natural and anthropogenic sources elsewhere in the Northern Hemisphere. This distinct difference in source regions for $\mathrm{O}_{3}$ and its precursors, and the altitude variations of the regional influences, highlights the complex transport pathways that bring air from other parts of the world to this region.

Although our conclusions are based on an analysis in 2005, the consistency between our 2005 analysis and an 8year (2005-2012) climatology suggests that our analysis provides a good representation for the free tropospheric $\mathrm{O}_{3}$ variations over the Middle East. However, noticeable discrepancies were obtained for some regional contributions; for example, the 8-year mean Asian contribution is $10 \%$ lower than that in 2005. In future studies, we will investigate the influences of changes in emissions and interannual variations in the meteorological conditions on free tropospheric $\mathrm{O}_{3}$ over the Middle East and across the Northern Hemisphere to provide critical information for enhanced understanding of the processes contributing to variations in tropospheric $\mathrm{O}_{3}$.

\section{Data availability}

The TES lite product is available at http://avdc.gsfc.nasa.gov/ index.php?site $=635564035 \& \mathrm{id}=10$.

Acknowledgements. This research was carried out at the Jet Propulsion Laboratory, California Institute of Technology, under a contract with the National Aeronautics and Space Administration.

Edited by: M. Van Roozendael

\section{References}

Barth, M. C., Lee, J., Hodzic, A., Pfister, G., Skamarock, W. C., Worden, J., Wong, J., and Noone, D.: Thunderstorms and upper troposphere chemistry during the early stages of the 2006 North American Monsoon, Atmos. Chem. Phys., 12, 11003-11026, doi:10.5194/acp-12-11003-2012, 2012.

Beer, R., Glavich, T. A., and Rider, D. M.: Tropospheric emission spectrometer for the Earth Observing System's Aura satellite, Appl. Optics, 40, 2356-2367, 2001.

Bela, M. M., Longo, K. M., Freitas, S. R., Moreira, D. S., Beck, V., Wofsy, S. C., Gerbig, C., Wiedemann, K., Andreae, M. O., and Artaxo, P.: Ozone production and transport over the Amazon Basin during the dry-to-wet and wet-to-dry transition seasons, Atmos. Chem. Phys., 15, 757-782, doi:10.5194/acp-15757-2015, 2015.

Benkovitz, C. M., Scholtz, M. T., Pacyna, J., Tarrasón, L., Dignon, J., Voldner, E. C., Spiro, P. A., Logan, J. A., and Graedel, T. E.: Global gridded inventories of anthropogenic emissions of sulfur and nitrogen, J. Geophys. Res., 101, 29239-29253, doi:10.1029/96JD00126, 1996.

Cristofanelli, P., Scheel, H.-E., Steinbacher, M., Saliba, M., Azzopardi, F., Ellul, R., Fröhlich, M., Tositti, L., Brattich, E., Maione, M., Calzolari, F., Duchi, R., Landi, T. C., Marinoni, A., and Bonasoni, P.: Long-term surface ozone variability at Mt. Cimone WMO/GAW global station (2165 m a.s.l., Italy), Atmos. Environ., 101, 23-33, doi:10.1016/j.atmosenv.2014.11.012, 2014.

Fu, T., Jacob, D., Palmer, P., Chance, K., Wang, Y., Barletta, B., Blake, D., Stanton, J., and Pilling, M.: Space based formaldehyde measurements as constraints on volatile organic compound emissions in east and south Asia and implications for ozone, J. Geophys. Res., 112, D06312, doi:10.1029/2006JD007853, 2007.

Henze, D. K., Hakami, A., and Seinfeld, J. H.: Development of the adjoint of GEOS-Chem, Atmos. Chem. Phys., 7, 2413-2433, doi:10.5194/acp-7-2413-2007, 2007.

Jiang, Z., Jones, D. B. A., Worden, H. M., and Henze, D. K.: Sensitivity of top-down $\mathrm{CO}$ source estimates to the modeled vertical structure in atmospheric CO, Atmos. Chem. Phys., 15, 15211537, doi:10.5194/acp-15-1521-2015, 2015a.

Jiang, Z., Worden, J. R., Jones, D. B. A., Lin, J.-T., Verstraeten, W. W., and Henze, D. K.: Constraints on Asian ozone using Aura TES, OMI and Terra MOPITT, Atmos. Chem. Phys., 15, 99-112, doi:10.5194/acp-15-99-2015, 2015 b.

Kuhns, H., Green, M., and Etyemezian, V.: Big Bend Regional Aerosol and Visibility Observational (BRAVO) Study Emissions Inventory, Report prepared for BRAVO Steering Committee, Desert Research Institute, Las Vegas, Nevada, USA, 2003.

Lamsal, L., Martin, R., Padmanabhan, A., Donkelaar, A., Zhang, Q., Sioris, C., Chance, K., Kurosu, T., and Newchurch, M.: Application of satellite observations for timely updates to global anthropogenic $\mathrm{NO}_{x}$ emission inventories, Geophys. Res. Lett., 38, L05810, doi:10.1029/2010GL046476, 2011.

Lapina, K., Henze, D. K., Milford, J. B., Huang, M., Lin, M., Fiore, A. M., Carmichael, G., Pfister, G. G., and Bowman, K.: Assessment of source contributions to seasonal vegetative exposure to ozone in the U.S., J. Geophys. Res.-Atmos., 119, 324-340, 2014.

Lelieveld, J., Hoor, P., Jöckel, P., Pozzer, A., Hadjinicolaou, P., Cammas, J.-P., and Beirle, S.: Severe ozone air pollution in the Persian Gulf region, Atmos. Chem. Phys., 9, 1393-1406, doi:10.5194/acp-9-1393-2009, 2009.

Li, Q., Jacob, D. J., Logan, J. A., Bey, I., Yantosca, R. M., Liu, H., Martin, R. V., Fiore, A. M., Field, B. D., Duncan, B. N., and Thouret, V.: A Tropospheric Ozone Maximum Over the Middle East, Geophys. Res. Lett., 28, 3235-3238, doi:10.1029/2001GL013134, 2001.

Liu, J., Jones, D. B., Worden, J., Noone, D., Parrington, M., and Kar, $\mathrm{J}$.: Analysis of the summertime buildup of tropospheric ozone abundances over the Middle East and North Africa as observed by the Tropospheric Emission Spectrometer instrument, J. Geophys. Res., 114, D05304, doi:10.1029/2008JD010993, 2009. 
Liu, J., Jones, D. B., Zhang, S., and Kar, J.: Influence of interannual variations in transport on summertime abundances of ozone over the Middle East, J. Geophys. Res., 116, D20310, doi:10.1029/2011JD016188, 2011.

Millet, D. B., Jacob, D. J., Boersma, K. F., Fu, T.-M., Kurosu, T. P., Chance, K., Heald, C. L., and Guenther, A.: Spatial distribution of isoprene emissions from North America derived from formaldehyde column measurements by the OMI satellite sensor, J. Geophys. Res., 113, D02307, doi:10.1029/2007JD008950, 2008.

Miyazaki, K., Eskes, H. J., and Sudo, K.: Global NO $\mathrm{N}_{x}$ emission estimates derived from an assimilation of OMI tropospheric $\mathrm{NO}_{2}$ columns, Atmos. Chem. Phys., 12, 2263-2288, doi:10.5194/acp12-2263-2012, 2012.

Miyazaki, K., Eskes, H. J., Sudo, K., and Zhang, C.: Global lightning $\mathrm{NO}_{x}$ production estimated by an assimilation of multiple satellite data sets, Atmos. Chem. Phys., 14, 3277-3305, doi:10.5194/acp-14-3277-2014, 2014.

Miyazaki, K., Eskes, H. J., and Sudo, K.: A tropospheric chemistry reanalysis for the years 2005-2012 based on an assimilation of OMI, MLS, TES, and MOPITT satellite data, Atmos. Chem. Phys., 15, 8315-8348, doi:10.5194/acp-15-8315-2015, 2015.

Neu, J., Flury, T., Manney, G., Santee, M., Livesey, N., and Worden, J.: Tropospheric ozone variations governed by changes in stratospheric circulation, Nat. Geosci., 7, 340-344, doi:10.1038/ngeo2138, 2014.

Olivier, J. G. J. and Berdowski, J. J. M.: Global emissions sources and sinks, in: The Climate System, edited by: Berdowski, J., Guicherit, R., and Heij, B. J., A. A. Balkema Publishers/Swets \& Zeitlinger Publishers, Lisse, the Netherlands, 33-78, 2001.

Ott, L. E., Pickering, K. E., Stenchikov, G. L., Allen, D. J., DeCaria, A. J., Ridley, B., Lin, R.-F., Lang, S., and Tao, W.-K.: Production of lightning $\mathrm{NO}_{x}$ and its vertical distribution calculated from three-dimensional cloud-scale chemical transport model simulations, J. Geophys. Res., 115, D04301, doi:10.1029/2009JD011880, 2010.

Park, M., Randel, W. J., Gettelman, A., Massie, S. T., and Jiang, J. H.: Transport above the Asian summer monsoon anticyclone inferred from Aura Microwave Limb Sounder tracers, J. Geophys. Res, 112, D16309, doi:10.1029/2006JD008294, 2007.

Pickering, K. E., Wang, Y., Tao, W. K., Price, C., and Muller, J. F.: Vertical distributions of lightning $\mathrm{NO}_{x}$ for use in regional and global chemical transport models, J. Geophys. Res., 103, 3120331216, doi:10.1029/98JD02651, 1998.

Rex, M., Wohltmann, I., Ridder, T., Lehmann, R., Rosenlof, K., Wennberg, P., Weisenstein, D., Notholt, J., Krüger, K., Mohr, V., and Tegtmeier, S.: A tropical West Pacific $\mathrm{OH}$ minimum and implications for stratospheric composition, Atmos. Chem. Phys., 14, 4827-4841, doi:10.5194/acp-14-4827-2014, 2014.

Ricaud, P., Sič, B., El Amraoui, L., Attié, J.-L., Zbinden, R., Huszar, P., Szopa, S., Parmentier, J., Jaidan, N., Michou, M., Abida, R., Carminati, F., Hauglustaine, D., August, T., Warner, J., Imasu, R., Saitoh, N., and Peuch, V.-H.: Impact of the Asian monsoon anticyclone on the variability of mid-to-upper tropospheric methane above the Mediterranean Basin, Atmos. Chem. Phys., 14, 1142711446, doi:10.5194/acp-14-11427-2014, 2014.

Safieddine, S., Boynard, A., Coheur, P.-F., Hurtmans, D., Pfister, G., Quennehen, B., Thomas, J. L., Raut, J.-C., Law, K. S., Klimont, Z., Hadji-Lazaro, J., George, M., and Clerbaux, C.:
Summertime tropospheric ozone assessment over the Mediterranean region using the thermal infrared IASI/MetOp sounder and the WRF-Chem model, Atmos. Chem. Phys., 14, 1011910131, doi:10.5194/acp-14-10119-2014, 2014.

Schumann, U. and Huntrieser, H.: The global lightning-induced nitrogen oxides source, Atmos. Chem. Phys., 7, 3823-3907, doi:10.5194/acp-7-3823-2007, 2007.

Spohn, T. and Rappenglück, B.: Tracking potential sources of peak ozone concentrations in the upper troposphere over the Arabian Gulf region, Atmos. Environ., 101, 257-269, doi:10.1016/j.atmosenv.2014.11.026, 2014.

Sudo, K. and Akimoto, H.: Global source attribution of tropospheric ozone: Long-range transport from various source regions, J. Geophys. Res., 112, D12302, doi:10.1029/2006JD007992, 2007.

van der Werf, G. R., Randerson, J. T., Giglio, L., Collatz, G. J., Mu, M., Kasibhatla, P. S., Morton, D. C., DeFries, R. S., Jin, Y., and van Leeuwen, T. T.: Global fire emissions and the contribution of deforestation, savanna, forest, agricultural, and peat fires (19972009), Atmos. Chem. Phys., 10, 11707-11735, doi:10.5194/acp10-11707-2010, 2010.

Vestreng, V. and Klein, H.: Emission data reported to UNECE/EMEP. Quality assurance and trend analysis and Presentation of WebDab, MSC-W Status Report, Norwegian Meteorological Institute, Oslo, Norway, 2002.

Vogel, B., Günther, G., Müller, R., Grooß, J.-U., Hoor, P., Krämer, M., Müller, S., Zahn, A., and Riese, M.: Fast transport from Southeast Asia boundary layer sources to northern Europe: rapid uplift in typhoons and eastward eddy shedding of the Asian monsoon anticyclone, Atmos. Chem. Phys., 14, 12745-12762, doi:10.5194/acp-14-12745-2014, 2014.

Wang, Y., Jacob, D. J., and Logan, J. A.: Global simulation of tropospheric $\mathrm{O}_{3}-\mathrm{NO}_{x}$-hydrocarbon chemistry: 1. Model formulation, J. Geophys. Res., 103, 10713-10725, doi:10.1029/98JD00158, 1998.

Worden, J., Jones, D., Liu, J., Parrington, M., Bowman, K., Stajner, I., Beer, R., Jiang, J., Thouret, V., Kulawik, S., Li, J., Verma, S., and Worden, H.: Observed vertical distribution of tropospheric ozone during the Asian summertime monsoon, J. Geophys. Res., 114, D13304, doi:10.1029/2008JD010560, 2009.

Yienger, J. J. and Levy II, H.: Empirical model of global soilbiogenic $\mathrm{NO}_{\chi}$ emissions, J. Geophys. Res., 100, 11447-11464, doi:10.1029/95JD00370, 1995.

Zanis, P., Ganser, A., Zellweger, C., Henne, S., Steinbacher, M., and Staehelin, J.: Seasonal variability of measured ozone production efficiencies in the lower free troposphere of Central Europe, Atmos. Chem. Phys., 7, 223-236, doi:10.5194/acp-7-223-2007, 2007.

Zanis, P., Hadjinicolaou, P., Pozzer, A., Tyrlis, E., Dafka, S., Mihalopoulos, N., and Lelieveld, J.: Summertime free-tropospheric ozone pool over the eastern Mediterranean/Middle East, Atmos. Chem. Phys., 14, 115-132, doi:10.5194/acp-14-115-2014, 2014.

Zhang, Q., Streets, D. G., Carmichael, G. R., He, K. B., Huo, H., Kannari, A., Klimont, Z., Park, I. S., Reddy, S., Fu, J. S., Chen, D., Duan, L., Lei, Y., Wang, L. T., and Yao, Z. L.: Asian emissions in 2006 for the NASA INTEX-B mission, Atmos. Chem. Phys., 9, 5131-5153, doi:10.5194/acp-9-5131-2009, 2009. 